\title{
Characterization of Angiotensin-Converting Enzyme before and after Cryopreservation of Gir Semen
}

\author{
Fernando H. G. Furtado1, Fábio J. C. Faria1, Elisvânia F. Santos², \\ Ricardo G. Almeida ${ }^{1}$, Deiler S. Costa ${ }^{1^{*}}$ \\ ${ }^{1}$ Lab of Assisted Reproduction-FAMEZ, Federal University of Mato Grosso do Sul, Campo Grande, Brazil \\ ${ }^{2}$ Institute of Biology_INBIO, Federal University of Mato Grosso do Sul, Campo Grande, Brazil \\ Email: *deilercosta@yahoo.com.br
}

How to cite this paper: Furtado, F.H.G., Faria, F.J.C., Santos, E.F., Almeida, R.G and Costa, D.S. (2019) Characterization of Angiotensin-Converting Enzyme before and after Cryopreservation of Gir Semen. Agricultural Sciences, 10, 638-650. https://doi.org/10.4236/as.2019.105049

Received: April 8, 2019

Accepted: May 13, 2019

Published: May 16, 2019

Copyright $\odot 2019$ by author(s) and Scientific Research Publishing Inc. This work is licensed under the Creative Commons Attribution International License (CC BY 4.0).

http://creativecommons.org/licenses/by/4.0/

\begin{abstract}
The aim of this study was to characterize the angiotensin-converting enzyme (ACE) in Gir semen before and after cryopreservation. The ejaculate of five sexually mature bulls was used. After collection, one 1-mL aliquot of fresh semen was analyzed immediately, and the rest of the semen was cryopreserved in liquid nitrogen for subsequent analysis. Freshly collected semen and thawed cryopreserved semen were centrifuged twice with Tyrode's albumin lactate pyruvate medium (TALP) to remove plasma and extender, respectively. Samples were then subjected to western blotting, immunocytochemistry, and enzymatic activity techniques. At least one $100 \mathrm{kDa}$ band was observed in every bull analyzed using western blotting with an anti-ACE monoclonal antibody, and band intensity decreased by $70 \%(\mathrm{p}<0.05)$ after cryopreservation. Immunocytochemistry showed periacrosomal ACE localization, and the area stained by the fluorescent antibody significantly decreased $(\mathrm{p}<0.05)$ after cryopreservation. Enzyme activity was evaluated using FAPGG substrate hydrolysis, which was significantly lower $(\mathrm{p}<0.05)$ in cryopreserved semen than in fresh semen. Therefore, the process of cryopreservation decreases ACE band intensity and enzyme activity in Gir bull semen, and reduces the stained area in immunocytochemistry.
\end{abstract}

\section{Keywords}

Bovine, Spermatozoid, Seminal Proteomics

\section{Introduction}

The process of semen cryopreservation becomes fundamental since acquiring a 
bull of high genetic value is costly. Artificial insemination with frozen semen achieves satisfactory pregnancy rates, but the process of cryopreservation can still lead to approximately $50 \%$ loss in sperm viability [1]. During this process, the plasma membrane undergoes structural alterations, mainly during the cooling stage (from $19^{\circ} \mathrm{C}$ to $8^{\circ} \mathrm{C}$ ), where it passes from a liquid to a gel state [2], and these changes are the main cause of intracellular ice crystal formation, excessive influx of calcium ions, and cell dehydration, resulting in decreased sperm fertilization capacity [3].

Sperm alterations resulting from cryopreservation also include changes in protein composition of both seminal fluid and the sperm membrane [4]. Nauc and Manjunath [5] reported a $70 \%-80 \%$ decrease in the concentration of BSP-A1-A2, BSP 0A3, and BSP-30 kDa proteins in bovine seminal plasma after cryopreservation when compared to fresh bovine semen, and these proteins were later positively correlated with the freezing capacity of bovine semen [3]. Westfalewicz et al. [3] studied protein changes in sperm membrane due to cryopreservation, and reported altered expression of 16 proteins, which mostly decreased after the freezing/thawing process.

Angiotensin-converting enzyme (ACE) is one of the sperm membrane proteins. It is a zinc-dependent metalloprotease that is anchored to the cell plasma membrane, with most of its mass exposed on the cell surface [6]. This enzyme has a somatic and a testicular isoform. The somatic isoform (sACE) has a molecular weight of $150-180 \mathrm{kDa}$, is found in several organs, and plays a fundamental role in blood pressure control, converting angiotensin I (inactive peptide) into angiotensin II (vasoactive peptide) in the renin-angiotensin-aldosterone system, in addition to inhibiting bradykinin (vasodilator peptide), which results in increased blood pressure. This action is inhibited by some substances, such as captopril and enalapril, which are widely used to treat high blood pressure [6] [7].

The testicular isoform (tACE) has lower molecular weight (90 - $110 \mathrm{kDa})$. tACE and sACE are transcribed by the same gene, but tACE uses a specific testicular promoter and is found only in germinal testicular cells after meiosis [6]. Its expression is 2.5 -fold higher on the sperm surface of abnormal human spermatozoa [8], and its enzyme activity increases in the spermatozoa of infertile men [9]. The larger amount in abnormal spermatozoa is due to a failure in ACE release during fertilization [8]. Its presence is fundamental for correct fertilization, since tACE knockout mice exhibit compromised fertility [10].

Therefore, data in the literatures on how the cryopreservation process changes ACE characteristics are scarce. Thus, the aim of this study was to evaluate intensity, immunolocalization, and enzymatic activity of ACE protein before and after cryopreserving the semen of bulls.

\section{Materials and Methods}

\subsection{Animals, Semen Collection and Cryopreservation}

Semen samples from five sexually mature Gir bulls (Bos taurus indicus) were 
used. Collections were performed using the electroejaculation method. After collection, motility, vigor, concentration, and sperm morphology of each ejaculate were evaluated [11].

Each bull's ejaculate was diluted in tris-egg yolk extender (2.42\% tris, $1.36 \%$ citric acid, $1 \%$ fructose, $7 \%$ glycerol, $20 \%$ egg yolk, and $0.7 \%$ gentamicin) at the concentration of $8 \times 10^{7}$ spermatozoa/mL, and stored in $0.5 \mathrm{~mL}$ straws. The semen was frozen using a TK 4000 portable programmable cryopreservation system (TK Reproduction Equipment, Uberaba, Brazil). This system uses a $-0.25^{\circ} \mathrm{C} /$ min cooling rate until reaching $5^{\circ} \mathrm{C}$, holds this temperature for 5 hours, and then a $-15^{\circ} \mathrm{C} / \mathrm{min}$ freezing rate from $5^{\circ} \mathrm{C}$ to $-80^{\circ} \mathrm{C}$, and then $-10^{\circ} \mathrm{C} / \mathrm{min}$ until reaching $-140^{\circ} \mathrm{C}$ [12]. Finally, the straws were placed in racks and stored in cryogenic tanks at $-196^{\circ} \mathrm{C}$ for at least two days before the evaluation.

\subsection{Sperm Pellet Preparation}

Fresh semen sperm pellets were prepared immediately after collection, using one 1 -mL sample that was centrifuged twice at $700 \times g$ for 30 minutes with TALP [13], at room temperature, to remove seminal plasma. Supernatant was discarded, and the pellet was used for subsequent analyses.

Frozen/thawed semen sperm pellets were prepared 48 hours after storage in cryogenic tanks. Ten straws were thawed in a $37^{\circ} \mathrm{C}$ water bath for 30 seconds. The semen was then placed in the same tube and centrifuged twice at $700 \times g$ for 30 minutes, at room temperature, with TALP to remove the extender. Supernatant was discarded, and the pellet was used for subsequent analyses.

\subsection{Western Blot}

The sperm pellet concentration of fresh and frozen/thawed semen was measured to detect $\mathrm{ACE}$, and $100-\mu \mathrm{L}$ aliquots containing $1 \times 10^{7}$ spermatozoa were subjected to protein extraction with $25 \mu \mathrm{L}$ sample buffer (10\% DL-Dithiothreitol, $0.004 \%$ bromophenol blue, $20 \%$ glycerol, $4 \%$ sodium dodecyl sulfate), and heated at $100^{\circ} \mathrm{C}$ for 5 minutes in a thermoblock heating system. Samples were then centrifuged at $10,000 \times g$ for 5 minutes.

The supernatant was electrophoresed (SDS-PAGE) and transferred to nitrocellulose membranes in transfer buffer ( $25 \mathrm{mM}$ Tris, $0.2 \mathrm{M}$ glycine, and $20 \%$ methyl alcohol, $\mathrm{pH}$ 8.5) at a constant voltage of $100 \mathrm{~V}$ [14]. The resulting nitrocellulose membranes were stained with $0.2 \%$ Ponceau $S$ in acetic acid to determine electrotransfer efficacy. Subsequently, nonspecific binding sites were blocked using 3\% skim milk in tris-buffered saline + Tween-20 (TTBS) $(20 \mathrm{mM}$ Tris, pH 7.8, containing $0.1 \%$ Tween-20) for 60 minutes. The membranes were then incubated (overnight at $4^{\circ} \mathrm{C}$ ) with an anti-ACE primary antibody (anti-ACE, clone E2, Millipore, 1:5000 in TTBS). Then, the membranes were washed three times with TTBS, and incubated with the secondary antibody (goat anti-mouse IgG, HRP conjugate, Millipore, 1:500 in TTBS) for 60 minutes at 
room temperature. After washing three times with TTBS, the protein bands were identified by chemiluminescence [15].

To confirm that all samples had the same amount of protein, another gel was prepared with the same samples, which was then examined by western blotting with an anti- $\beta$-tubulin antibody $(1: 10,000)[16]$.

Pixel intensity of protein bands was compared using the ImageJ 1.40 software. The gray scale ranges from zero to 250 , where zero represents a totally black image, and 250 represents a totally white image. Therefore, the closer to zero the band pixel intensity is, the more protein in the sample.

\subsection{Immunocytochemistry}

To determine ACE localization in spermatozoa, $10 \mu \mathrm{L}$ of fresh and frozen/thawed semen pellet was diluted in $1 \mathrm{~mL}$ of PBS. Spermatozoa were fixed with $4 \%$ paraformaldehyde in PBS, and then permeabilized with $0.5 \%(\mathrm{v} / \mathrm{v})$ Triton X-100 in PBS. Aliquots of $50 \mu \mathrm{L}\left(1 \times 10^{7}\right.$ spermatozoa $)$ were deposited on slides previously treated with poly-L-lysine and incubated at room temperature for 60 minutes. Next, excess spermatozoa were washed with PBS and nonspecific sites were blocked with 3\% BSA in PBS for 60 minutes. Subsequently, the slides were incubated with an anti-ACE primary antibody (anti-ACE, clone E2, Millipore, 1:250) diluted in $0.05 \% \mathrm{BSA}-\mathrm{PBS}$ at $4^{\circ} \mathrm{C}$ overnight. After washing three times with PBS, the samples were incubated with an anti-mouse IgG secondary antibody (goat anti-mouse IgG, HRP conjugate, Millipore, 1:400). After washing three more times with PBS to remove excess antibody, the slides were stained with $5 \mu \mathrm{g} / \mathrm{mL}$ Hoechst 33258, and $5 \mu \mathrm{g} / \mathrm{mL}$ Pisum sativum fluorescein isocyanate (FITC-PSA), and then mounted with 1.4-Diazabicyclo[2.2.2] octan (DABCO) [15]. The slides were evaluated under fluorescence microscopy (excitation peak $550 \mathrm{~nm}$ and emission $570 \mathrm{~nm}$ ), 200 cells were evaluated.

\subsection{Enzyme Activity}

ACE activity was determined based on the hydrolysis of furyl-acryloyl-L-phenylalanyl-glycyl-glycine (FAPGG) to furanacryloyl-L-phenylalanine and glycyl-glycine in a continuous spectrophotometric assay, as previously described by Holmquist et al. [17] and Ball et al. [18]. The fresh semen and frozen/thawed semen pellets were resuspended at a concentration of $1 \times 10^{8}$ spermatozoa $/ \mathrm{mL}$, and incubated in TALP with $1 \%$ Triton $\mathrm{X}$ at $4^{\circ} \mathrm{C}$ for 60 minutes. After detergent extraction, samples were centrifuged at $10,000 \times g$ for $30 \mathrm{~min}$, and then $100 \mu \mathrm{L}$ of supernatant was added to $900 \mu \mathrm{L}$ of FAPGG (45 mM in DMSO) diluted 1:30 in $0.05 \mathrm{M}$ Tris, $\mathrm{pH} 7.5$, containing $0.3 \mathrm{M}$ of $\mathrm{NaCl}$. FAPGG degradation was measured every minute by the decrease of absorbance reading in spectrophotometer for eight minutes, and these values were converted to enzyme activity expressed in $\mathrm{mU} / \mathrm{mL}^{-1}$. One unit is equivalent to the hydrolysis of $10^{-6} \mathrm{M}$ of FAPGG. Samples were evaluated in triplicate and reaction specificity was determined by adding the ACE inhibitor captopril $(10 \mu \mathrm{M})$. 


\subsection{Statistical Analysis}

The mean values of areas stained in immunocytochemistry, mean number of pixels in protein bands, and enzyme activity were subjected to analysis of variance (test $\mathrm{F}$ ), and the differences between groups were compared using the Student's test, considering a 0.05 significance threshold.

\subsection{Ethics Approval}

The project underwent ethical review and was given approval by an institutional animal care and use committee (Protocolo 5132013). All international guidelines for the care and use of animals for scientific purposes were followed in this experiment.

\section{Results}

\subsection{Western Blot}

The anti-ACE monoclonal antibody recognized at least one protein band of approximately $100 \mathrm{kDa}$ in the sperm suspension before (Figure 1(a)) and after (Figure 1(b)) semen cryopreservation from each of the five sexually mature Gir bulls analyzed. The process of cryopreservation resulted in an increased number of pixels in protein bands, and in the gray scale, the mean intensity was 82.973 pixels before freezing, and 174.64 pixels after freezing (Figure 2), representing a $47.5 \%$ reduction in mean protein amount $(\mathrm{p}<0.05)$.

To confirm if the same amount of protein was added to all samples, western blotting was performed with an anti- $\beta$-tubulin antibody. Band intensities were the same for the five bulls (Figure 3), with no difference in pixel number among samples ( $p>0.05$ ), showing that the same amount of protein was added to each sample.

\subsection{Immunocytochemistry}

ACE immunodetection in the spermatozoa of five Gir bulls showed periacrosomal ACE localization, and the cryopreservation process did not change ACE localization (Figure 4(a) and Figure 4(b)). The area stained in fresh semen was 519.6 pixels, while in the cryopreserved semen it was 238.33 pixels, representing a 55\% reduction (Figure 5, p < 0.05).

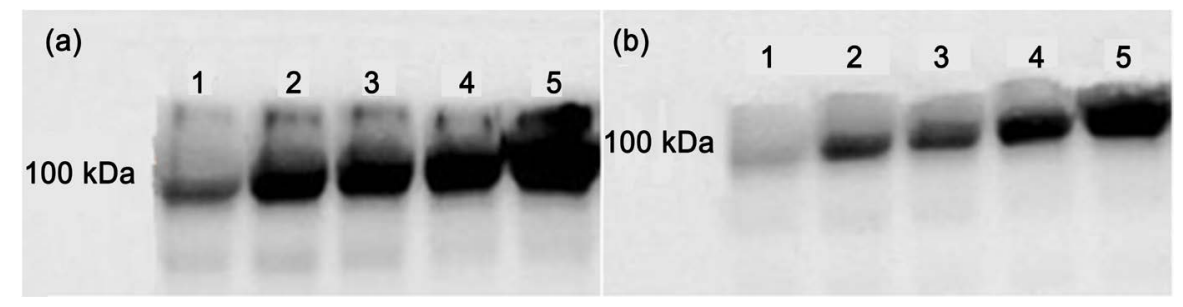

Figure 1. ACE immunodetection before (a) and after (b) cryopreservation of Gir semen. Western blot technique with anti-ACE monoclonal antibody. Each column represents a bull. 


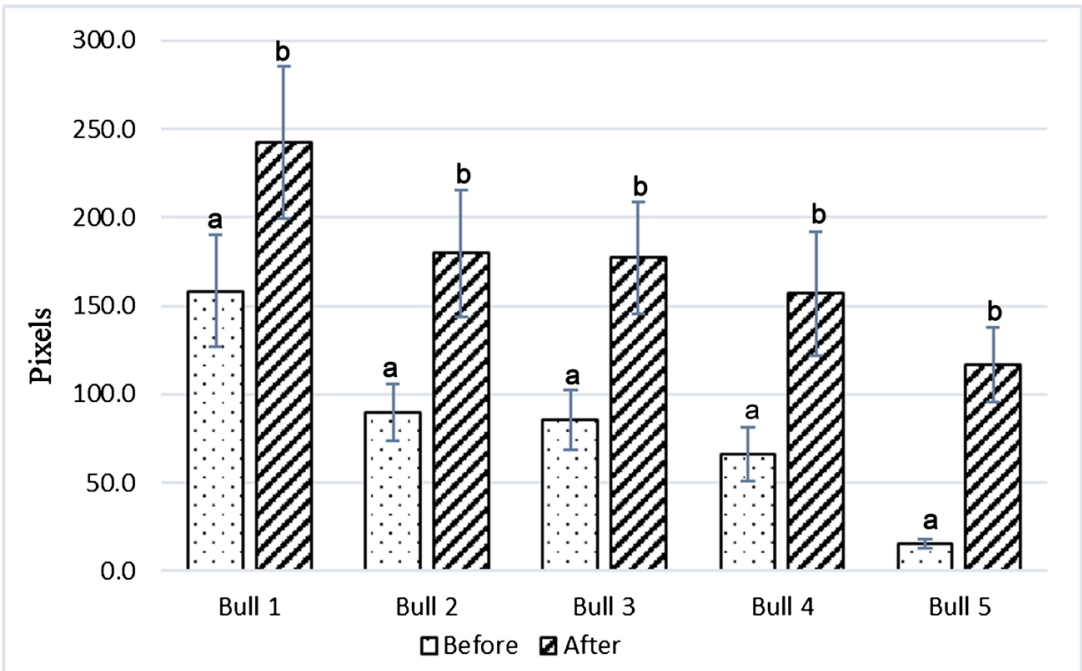

Figure 2. Pixel number in protein bands obtained using western blot and evaluated by ImageJ software. The higher the number of pixels, the clearer the protein band and the less protein detected. Mean band intensity decreased significantly after cryopreservation. Different letters represent a significant difference, determined by the $t$ test $(p<0.05)$.

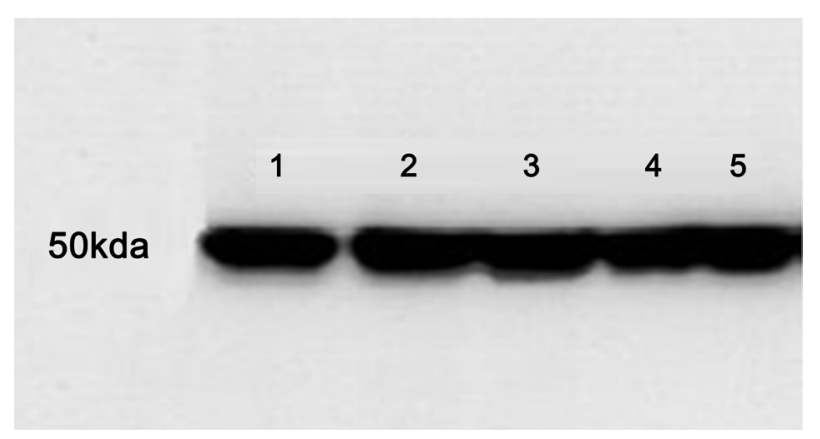

Figure 3. $\beta$-tubulin immunodetection in Gir semen. Western blot using an anti- $\beta$-tubulin monoclonal antibody. Each column represents a bull.
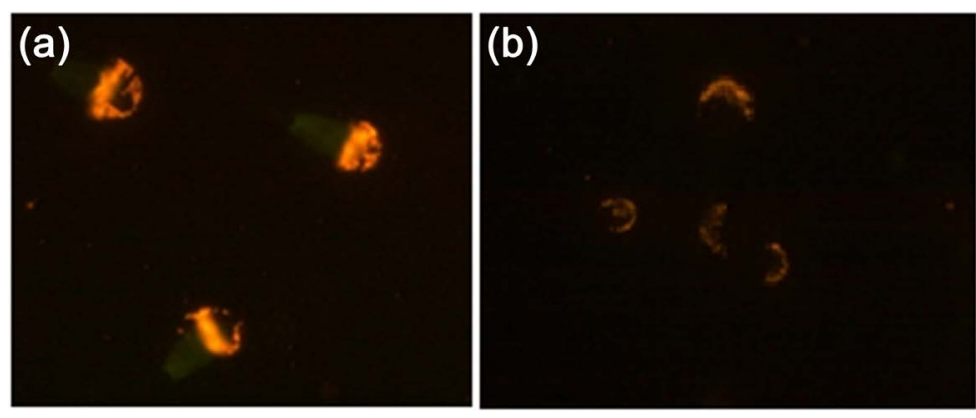

Figure 4. ACE immunolocalization in spermatozoids before (a) and after (b) cryopreservation of Gir semen. ACE was localized in the periacrosomal region.

\subsection{Enzyme Activity}

Figure 6 shows ACE enzyme activity before and after cryopreservation. The cryopreservation process led to a $47 \%$ reduction in ACE enzyme activity ( $\mathrm{p}<$ $0.05)$. 


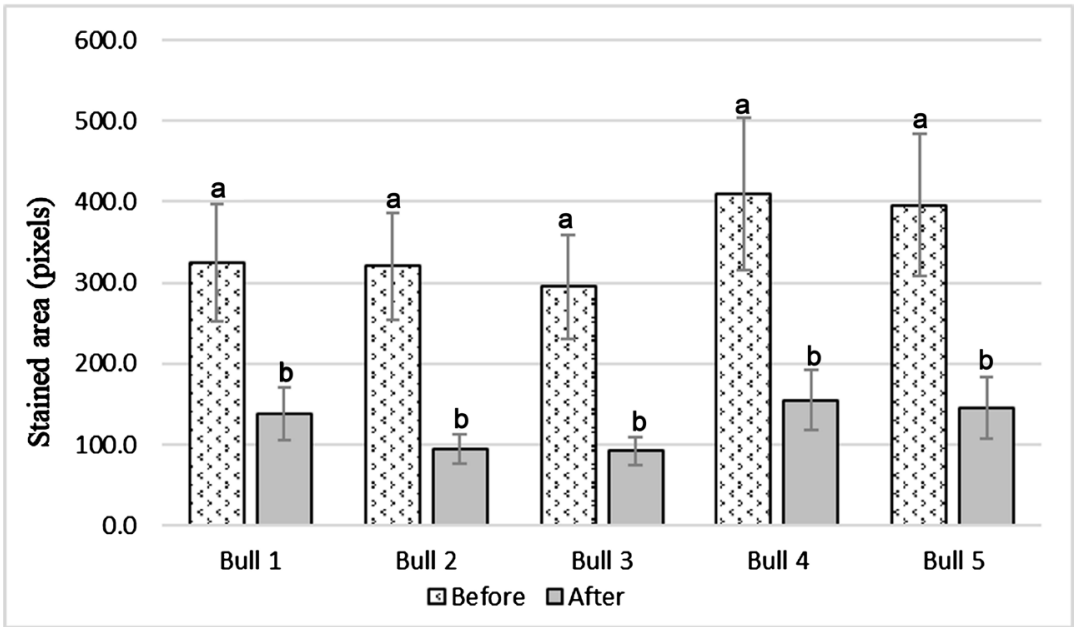

Figure 5. Mean spermatozoid stained area using an anti-ACE antibody conjugated to Cy3 fluorochrome was evaluated using Image J software. Results were obtained in pixels. Different letters represent a significant difference, determined by the $t$ test $(\mathrm{p}<0.05)$.

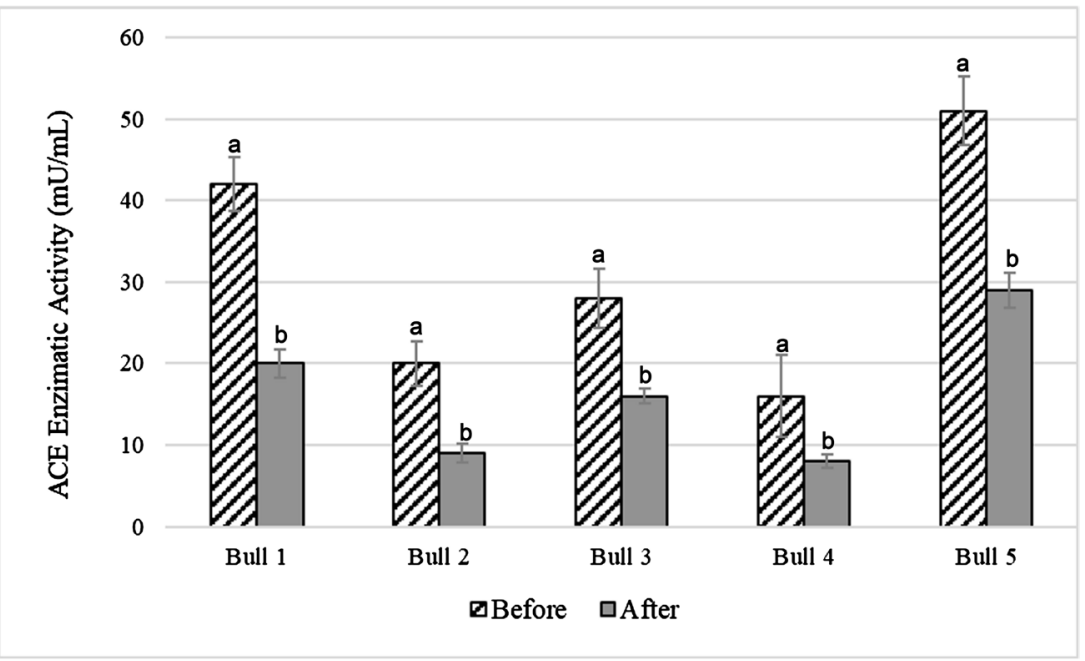

Figure 6. ACE enzyme activity before and after semen cryopreservation of five Gir bulls. ACE activity was determined by FAPGG hydrolysis. Each unit is equivalent to the hydrolysis of $10^{-6} \mathrm{M}$ of FAPGG. Different letters represent a significant difference, determined by the $t$ test $(\mathrm{p}<0.05)$.

\section{Discussion}

The western blot technique with fresh sperm extract from five bulls identified at least one protein band with a molecular weight of $100 \mathrm{kDa}$ (Figure 1(a)) using an anti-ACE antibody. This result corroborates what is described for the ACE testicular isoform in other species, such as rabbits [19], pigs [20], humans [21], rats [22], sheep [23] and Holstein cattle [14]. However, Sabeur et al. [24], working with dogs, and Dobrinski et al. [25], working with horses, found tACE with molecular weights of $65-70$ and $68-70 \mathrm{kDa}$, respectively. According to these authors, this difference is due to different glycosylation levels among species, since the tACE molecular mass is $20 \%$ carbohydrate [19]. However, Nikolaeva et 
al. [8] suggest that this difference could be due to the use of a polyclonal antibody in these studies, which could have detected other enzymes. This present study used a monoclonal antibody, and the molecular weight found is compatible only with tACE.

After cryopreservation, the tACE bands found in the samples (Figure 1(b)) presented the same molecular weight as those found in fresh semen. However, a reduction in band intensity of approximately $47 \%$ was observed in samples after cryopreservation (Figure 2). Nauc and Manjunath [5] studied other proteins and reported an $84 \%, 79 \%$, and $74 \%$ reduction in the amounts of BSP-A1/-A2, BSP-A3, and BSP-30-kDa, respectively, in cryopreserved bovine sperm, while Yoon et al. [26] reported that sperm cryopreservation from bull epididymis changed the amount of nine proteins, seven of which showed increased expression (AKAP, F1-ATPase, TPI, NDPK7, NDUFV2, CAPZB, and SOD2), and two showed decreased expression (ODF2 and an unidentified protein), like the tACE in this study.

A quantity of ACE is released during sperm capacitation, while another part is released during the passage through the female reproductive tract [27]. Singh et al. [28] showed this release in cattle, and the reduction in ACE band intensity observed in this study corroborates these results, since according to Medeiros et al. [29], membrane alterations due to cryopreservation are similar to alterations observed in sperm capacitation. So, ACE would be released from the sperm membrane, similarly to what occurs in capacitation.

These changes in the protein composition of the sperm membrane and seminal plasma are one of the main causes of decreased sperm fertility after cryopreservation, since these proteins are involved in processes that are fundamental for fertilization, such as motility, acrosome reaction, transportation inside the female reproductive tract, zona pellucida attachment, and oocyte fusion [30]. Kondoh et al. [31] reported that tACE could release the extracellular portion of glycosylphosphatidylinositol (GPI) anchored protein; this ACE function would be directly related to oocyte fertilization by the sperm, independently of the previously known ACE proteolytic activity. Testicular germ cells are rich in anchored GPI proteins, and the authors identified a $110 \mathrm{kDa}$ factor during a systematic search for new factors capable of releasing such proteins that, after purification and proteomic analysis, was identified as tACE.

Many studies have correlated sperm parameters and bull fertility with some sperm proteins. For example, osteopontin (OPN), BSP $30 \mathrm{kDa}$, phospholipase $\mathrm{A} 2$, heparin-binding proteins (HBP), and $\mathrm{P} 25 \mathrm{~b}$ are positively correlated with fertility [32] [33]. On the other hand, spermadhesin z13 and clusterin showed a negative correlation [33] [34]. Similarly, Nikolaeva et al. [8] showed that tACE expression is altered in spermatozoa with low motility and/or morphological changes. These authors found a 2.5-fold higher tACE expression on the surface of abnormal human spermatozoa, corroborating the results by Siems et al. [35], and Kohn et al. [36]. Shibahara et al. [9] also found higher tACE activity in in- 
fertile human spermatozoa, which had reduced motility, and suggested that the released tACE in normal spermatozoa activates the fertilizing capacity. However, in defective cells, this enzyme cannot detach from the membrane, resulting in a greater ACE amount in these cells. On the other hand, tACE knockout mice exhibit reduced fertility, suggesting that tACE expression in spermatozoa is necessary for correct fertilization [10].

tACE localization seems to vary among species, and some studies reported different localizations within the same species. This protein has already been detected in the intermediate and initial portions of the flagellum in rat and mouse spermatozoa within the testes [37], in spermatids and cytoplasmic droplets of pig epididymal spermatozoa [20], around the spermatid head, spermatozoa and cytoplasmic droplet of rabbit seminal fluid [38], and in the acrosome or in the whole head, postacrosomal region, intermediate portion, flagellum, and equatorial region of human spermatozoa [36]. Nikolaeva et al. [8], detected tACE in the head and acrosome of human spermatids and spermatozoa using a monoclonal anti-ACE antibody, and according to these authors, the differences found in tACE localization, as also suggested by western blotting, are due to the low specificity of the polyclonal anti-ACE antibody.

In the present study, an anti-ACE mouse monoclonal antibody was used and detected ACE only in the periacrosomal region of Gir spermatozoa (Figure 4(a)). Costa and Thundathil [14] found the same localization using Holstein bulls. This periacrosomal localization was also described in other species, such as horses [25] and dogs [24].

Similar to western blot results, a decreased amount of tACE after cryopreservation was observed using immunocytochemistry, demonstrated by a $55 \%$ decrease in the mean stained area (Figure 5). However, enzyme localization in spermatozoa was not altered (Figure 4(a) and Figure 4(b)), suggesting that the process of cryopreservation releases ACE from the plasma membrane, corroborating the results obtained by Mohan et al. [39], where cryopreservation decreased the amount of ACE in spermatozoa and increased the amount in seminal plasma.

ACE in vitro enzymatic activity can be evaluated using two methods that use two different substrates. The method described by Kasahara and Ashihara [40] uses the synthetic compound hippuryl-histidyl leucine (hip-his-leu) as a substrate, and the method described by Holmquist et al. [17] uses FAPGG as substrate. Jaiswal et al. [41] found ACE enzyme activity in epididymal and testicular homogenates of albino rats, mice, pigs, guinea pigs, goats, rabbits, and buffalos, all using hip-his-leu as a substrate. ACE enzyme activity using FAPGG as a substrate was already found in human spermatozoa [36], canine testis [24], equine testis [18], and Holstein spermatozoa and seminal plasma [14].

In this study, ACE enzyme activity using FAPGG substrate was found in the semen of the five Gir bulls analyzed, corroborating the results obtained by Costa and Thundathil [14], who found ACE enzyme activity in both spermatozoa and 
seminal plasma of Holstein bulls also using FAPGG as substrate. Singh et al. [28] and Heder et al. [42] also found ACE enzyme activity in bovine semen, however, they used hip-his-leu as substrate. In addition, Figure 6 shows that ACE enzyme activity decreased in all cryopreserved samples compared to fresh samples, in accordance with western blot and immunocytochemistry results, which also showed decreased sperm ACE after cryopreservation.

ACE appears to behave differently in bird semen compared to mammalian semen. Mohan et al. [39] compared ACE enzyme activity in rooster, buffalo, and bull semen using hip-his-leu as a substrate, and concluded that ACE activity in birds is higher in seminal plasma than in spermatozoa, unlike what was observed in buffalos and bulls, which presented enzymatic activity 6.5-fold greater in spermatozoa than in plasma. In addition, after undergoing cold thermal shock $\left(0^{\circ} \mathrm{C}\right.$ for 10 minutes), enzyme activity in bird spermatozoa and plasma did not change. In buffalo and bull semen, ACE activity decreased in spermatozoa and increased in plasma.

The process of cryopreservation led to decreased ACE enzyme activity in Gir sperm as determined by decreased protein band intensity, without changing the molecular weight, and in immunofluorescence, without changing enzyme localization. All these results show that sperm lose ACE during the process of cryopreservation.

\section{Acknowledgements}

This work was supported by the Fundação de Apoio ao Desenvolvimento do Ensino, Ciência e Tecnologia do Estado de Mato Grosso do Sul (Processo: 23/200.655/2012).

\section{Conflicts of Interest}

The authors declare no conflicts of interest regarding the publication of this paper.

\section{References}

[1] Watson, P.F. (2000) The Causes of Reduced Fertility with Cryopreserved Semen. Animal Reproduction Science, 60, 481-492. https://doi.org/10.1016/S0378-4320(00)00099-3

[2] Graham, J.K. (2011) Principles of Cooled Semen. In: McKinnon, A.O., Squires, E.L., Vaala, W.E. and Varner, D.D., Eds., Equine Reproduction, 2nd Edition, Wiley Blackwell, West Sussex, 1308-1315.

[3] Jobim, M.I.M., Gregory, R.M. and Mattos, R.C. (2009) Proteínas do plasma seminal relacionadas a congelabilidade do sêmen bovino. Revista Brasileira de Reprodução Animal, 6, 25-31.

[4] Westfalewicz, B., Dietrich, M.A. and Ciereszko, A. (2015) Impact of Cryopreservation on Bull (Bos taurus) Semen Proteome. Journal of Animal Science, 93, 5240-5253. https://doi.org/10.2527/jas.2015-9237

[5] Nauc, V. and Manjunath, P. (2000) Radioimmunoassay for Bull Seminal Plasma 
Proteins (BSP-A1/A2, BSP-A3, and BSP-30 Kilodaltons), and Their Quantification in Seminal Plasma and Sperm. Biology of Reproduction, 63, 1058-1066. https://doi.org/10.1095/biolreprod63.4.1058

[6] Corvol, P., Eyries, M. and Soubrier, F. (2004) Peptidyl-Dipeptidase A: Angiotensin 1-Converting Enzyme. In: Barrett, A.J., Rawling, N.D. and Woessner, J.F., Eds., Handbook of Proteolytic Enzymes, 2nd Edition, Academic Press, San Diego, 332-346. https://doi.org/10.1016/B978-0-12-079611-3.50090-2

[7] Deguchi, E., Tani, T., Watanabe, H., Yamada, S. and Kondoh, G. (2007) Dipeptidase Inactivated tACE Action in Vivo: Selective Inhibition of Sperm-Zona Pellucida Binding in the Mouse. Biology of Reproduction, 77, 794-802. https://doi.org/10.1095/biolreprod.107.060004

[8] Nikolaeva, M.A., Balyasnikova, I.V., Alexinskaya, M.A., Metzger, R., Franke, F.E., Albrecht, R.F., Kulakov, V.I., Sukhikh, G.T. and Danilov, S.M. (2006) Testicular Isoform of Angiotensin I-Converting Enzyme (ACE, CD143) on the Surface of Human Spermatozoa: Revelation and Quantification Using Monoclonal Antibodies. American Journal of Reproductive Immunology, 55, 54-68. https://doi.org/10.1111/j.1600-0897.2005.00326.x

[9] Shibahara, H., Kamata, M., Hu, J., Nakagawa, H., Obara, H., Kondoh, N., Shima, H. and Sato, I. (2001) Activity of Testis Angiotensin Converting Enzyme (ACE) in Ejaculated Human Spermatozoa. International Journal of Andrology, 24, 295-299. https://doi.org/10.1046/j.1365-2605.2001.00301.x

[10] Hagaman, J.R., Moyer, J.S., Bachman, E.S., Sibony, M., Magyar, P.L., Welch, J.E., Smithies, O., Krege, J.H. and O’brien, D.A. (1998) Angiotensin-Converting Enzyme and Male Fertility. Proceedings of the National Academy of Sciences of the United States of America, 95, 2552-2557. https://doi.org/10.1073/pnas.95.5.2552

[11] Okano, D.S., Penitente-Filho, J.M., Gomez León, V.E., Maitan, P.P., Silveira, C.O., Waddington, B., Díaz-Miranda, E.A., da Costa, E.P., Guimarães, S.E.F. and Guimarães, J.D. (2019) In Vitro Evaluation of Cryopreserved Bovine Sperm and Its Relation to Field Fertility in Fixed-Time Artificial Insemination. Reproduction in Domestic Animals, 54, 604-612. https://doi.org/10.1111/rda.13401

[12] Dias, E.A.R, Campanholi, S.P., Rossi, G.F., Dell'Aqua, C.P.F., Junior, J.A.D., Papa, F.O., Zorzetto, M.F., Paz, C.C.P., Oliveira, L.Z., Mercadante, M.E.Z. and Monteiro, F.M. (2018) Evaluation of Cooling and Freezing Systems of Bovine Sêmen. Animal Reproduction Science, 195, 102-111.

https://doi.org/10.1016/j.anireprosci.2018.05.012

[13] Schenk, J.L., Suh, T.K., Cran, D.G. and Seidel Jr., G.E. (1999) Cryopreservation of Flow-Sorted Bovine Spermatozoa. Theriogenology, 52, 1375-1391.

https://doi.org/10.1016/S0093-691X(99)00224-1

[14] Costa, D.S. and Thundathil, J.C. (2012) Characterization and Activity of Angiotensin-Converting Enzyme in Holstein Semen. Animal Reproduction Science, 133, 35-42. https://doi.org/10.1016/j.anireprosci.2012.06.009

[15] Heytens, E., Parrington, J., Coward, K., Young, C., Lambrecht, S., Yoon, S.Y., Fissore, R.A., Hamer, R., Deane, C.M., Ruas, M., Grasa, P., Soleimani, R., Cuvelier, C.A., Gerris, J., Dhont, M., Deforce, D., Leybaert, L. and De Sutter, P. (2009) Reduced Amounts and Abnormal Forms of Phospholipase C Zeta (PLCzeta) in Spermatozoa from Infertile Men. Human Reproduction, 24, 2417-2428. https://doi.org/10.1093/humrep/dep207

[16] Peknicova, J., Pexidrova, M., Kubatova, A., Koubek, P., Tepla, O., Sulimenko, T. and Draber, P. (2007) Expression of Beta-Tubulin Epitope in Human Sperm with 
Pathological Spermiogram. Fertility and Sterility, 88, 1120-1128. https://doi.org/10.1016/j.fertnstert.2006.12.070

[17] Holmquist, B., Bunning, P. and Riordan, J.F. (1979) A Continuous Spectrophotometric Assay for Angiotensin Converting Enzyme. Analytical Biochemistry, 95, 540-548. https://doi.org/10.1016/0003-2697(79)90769-3

[18] Ball, B.A., Gravance, C.G., Wessel, M.T. and Sabeur, K. (2003) Activity of Angiotensin Converting Enzyme (ACE) in Reproductive Tissues of the Stallion and Effects of Angiotensin II on Sperm Motility. Theriogenology, 59, 901-914. https://doi.org/10.1016/S0093-691X(02)01127-5

[19] El-Dorry, H.A., Bull, H.G., Iwata, K., Thornberry, E.H. and Soffer, R.L. (1982) Molecular and Catalytic Properties of Rabbit Testicular Dipeptidyl Carboxypeptidase. The Journal of Biological Chemistry, 257, 14128-14133.

[20] Yotsumoto, H., Sato, S. and Shibuya, M. (1984) Localization of Angiotensin Converting Enzyme (Dipeptidyl Carboxypeptidase) in Swine Sperm by Immunofluorescence. Life Sciences, 35, 1257-1261. https://doi.org/10.1016/0024-3205(84)90096-1

[21] Ehlers, M.R.W., Maeder, D.L. and Kirsch, R.E. (1986) Rapid Affinity Chromatographic Purification of Human Lung and Kidney Angiotensin-Converting Enzyme with the Novel N-Carboxyalkyl Dipeptide Inhibitor N-[1(S)-carboxy-5-aminopentyl] Glycylglycine. Biochimica et Biophysica Acta, 883, 361-372. https://doi.org/10.1016/0304-4165(86)90329-6

[22] Langford, K.G., Zhou, Y., Russell, L.D., Wilcox, J.N. and Bernstein, K. (1993) Regulated Expression of Testis Angiotensin Converting Enzyme during Spermatogenesis in Mice. Biology of Reproduction, 48, 1210-1218.

https://doi.org/10.1095/biolreprod48.6.1210

[23] Gatti, J.L., Druart, X., Guerin, Y., Dacheux, F. and Dacheux, J.L. (1999) A 105 to 94 Kilodalton Protein in the Epididymal Fluids of Domestic Mammals Is Angiotensinconverting Enzyme (ACE), Evidence That Sperm Are the Source of ACE. Biology of Reproduction, 60, 937-945. https://doi.org/10.1095/biolreprod60.4.937

[24] Sabeur, K., Vo, A.T. and Ball, B.A. (2001) Characterization of Angiotensin-Converting Enzyme in Canine Testis. Reproduction, 122, 139-146.

https://doi.org/10.1530/rep.0.1220139

[25] Dobrinski, I., Ignotz, G.G., Fagnan, M.S., Ashley, I.Y. and Ball, B. (1997) Isolation and Characterization of a Protein with Homology to Angiotensin Converting Enzyme from the Periacrosomal Plasma Membrane of Equine Spermatozoa. Molecular Reproduction and Development, 48, 251-260. https://doi.org/10.1002/(SICI)1098-2795(199710)48:2<251::AID-MRD13>3.0.CO;2$\underline{0}$

[26] Yoon, S.J., Rahman, M.S., Kwon, W.S., Ryu, D.Y., Park, Y.J. and Pang, M.G. (2016) Proteomic Identification of Cryostress in Epididymal Spermatozoa. Journal of Animal Science and Biotechnology, 7, 67-79. https://doi.org/10.1186/s40104-016-0128-2

[27] Kamata, M., Hu, J., Shibahara, H. and Nakagawa, H. (2001) Assay of Testicular Angiotensin-Converting Enzyme Activity in Human Spermatozoa. International Journal of Andrology, 24, 225-231. https://doi.org/10.1046/j.1365-2605.2001.00288.x

[28] Singh, U.S., Kumar, M.V. and Panda, I.N. (1985) Angiotensin Converting Enzyme in Semen and Its Possible Role in Capacitation. Andrologia, 17, 472-475. https://doi.org/10.1111/j.1439-0272.1985.tb01044.x 
[29] Medeiros, C.M.O., Forrel, F., Oliveira, A.T.D. and Rodrigues, J.L. (2002) Current Status of Sperm Cryopreservation: Why Isn't Better? Theriogenology, 57, 327-344. https://doi.org/10.1016/S0093-691X(01)00674-4

[30] Moura, A.A., Chapman, D.A. and Killian, G.J. (2007) Proteins of the Accessory Sex Glands Associated with the Oocyte-Penetrating Capacity of Cauda Epididymal Sperm from Holstein Bulls of Documented Fertility. Molecular Reproduction and Development, 74, 214-222. https://doi.org/10.1002/mrd.20590

[31] Kondoh, G., Tojo, H., Nakatani, Y., Komazawa, N., Murata, C., Yamagata, K., Maeda, Y., Kinoshita, T., Okabe, M., Taguchi, R. and Takeda, J. (2005) Angiotensin-Converting Enzyme Is a GPI-Anchored Protein Releasing Factor Crucial for Fertilization. Nature Medicine, 11, 160-166. https://doi.org/10.1038/nm1179

[32] Parent, S., Lefièvre, L., Brindle, Y. and Sullivan, R. (1999) Bull Subfertility Is Associated with Low Levels of a Sperm Membrane Antigen. Molecular Reproduction and Development, 52, 57-65. https://doi.org/10.1002/(SICI)1098-2795(199901)52:1<57::AID-MRD8>3.3.CO;2-L

[33] Moura, A.A., Koc, H., Champman, D.A. and Killian, G.J. (2006) Identification of Proteins in the Accessory Sex Gland Fluid Associated with Fertility Indexes of Dairy Bulls: A Proteomic Approach. Journal of Andrology, 27, 201-211. https://doi.org/10.2164/jandrol.05089

[34] Ibrahim, N.M., Gilbert, G.R., Loseth, K.J. and Crabo, B.G. (2000) Correlation between Clusterin-Positive Spermatozoa Determined by Flow Cytometry in Bull Semen and Fertility. Journal of Andrology, 21, 887-894.

[35] Siems, W.E., Heder, G., Hilse, H., Baeger, I., Engel, S. and Jentzsch, K.D. (1991) Angiotensin-Converting Enzyme and Other Peptidolytic Enzymes in Human Semen and Relations to Its Spermatologic Parameters. Andrologia, 23, 185-189. https://doi.org/10.1111/j.1439-0272.1991.tb02533.x

[36] Kohn, F.M., Dammshauser, I., Neukamm, C., Renneberg, H., Siems, W.E., Schill, W.B. and Aumuller, G. (1998) Ultrastructural Localisation of Angiotensin Converting Enzyme in Ejaculated Spermatozoa. Human Reproduction, 13, 604-610. https://doi.org/10.1093/humrep/13.3.604

[37] Metayer, S., Dacheux, F., Dacheux, J.L. and Gatti, J.L. (2002) Germinal Angiotensin Converting Enzyme Is Totally Shed from the Rodent Sperm Membrane during Epididymal Maturation. Biology of Reproduction, 67, 1763-1767. https://doi.org/10.1095/biolreprod.102.006684

[38] Brentjens, J.R., Matsuo, S., Andres, G.A., Calwell, P.R.B. and Zomboni, L. (1986) Gametes Contain Angiotensin-Converting Enzyme (Kininase II). Experientia, 42, 399-402. https://doi.org/10.1007/BF02118626

[39] Mohan, J., Moudgal, R.P., Pandaland, J.N. and Mohan, G. (1992) Effects of Cold Shock Treatment on Angiotensin-Converting Enzyme Activity and on Semen Characteristics in Roosters and Bulls. Theriogenology, 37, 1147-1154. https://doi.org/10.1016/0093-691X(92)90111-4

[40] Kasahara, Y. and Ashihara, Y. (1981) Colorimetry of Angiotensin-I Converting Enzyme Activity in Serum. Clinical Chemistry, 27, 1922-1925.

[41] Jaiswal, A.K., Joshi, P., Kumar, M.V., Panda, L.N. and Singh, J.N. (1984) Angiotensin Converting Enzyme in the Testes and Epididymis of Mammals. Andrologia, 16, 410-416. https://doi.org/10.1111/j.1439-0272.1984.tb00385.x

[42] Heder, G., Siems, W.E., Nehring, H., Müller, K., Hilse, H. and Jentzsch, K.D. (1989) Occurrence and Potential Importance of Selected Peptidases in Bull Ejaculates. Andrologia, 21, 247-255. https://doi.org/10.1111/j.1439-0272.1989.tb02404.x 